UDC 36.74:004.738.5:657

DOI: $10.15673 /$ fie.v13i2.2041

\author{
Kurhan $\mathbf{N}$. \\ Ph.D., Assistant Professor \\ Department of Accounting and Business Consulting \\ E-mail: nsk11104@ukr.net \\ ORCID ID: 0000-0003-1155-6859 \\ Aksyuta V. \\ Undergraduate \\ Department of Accounting and Business Consulting \\ Simon Kuznets Kharkiv National University of Economics \\ prospect Nauki, 9-A, Kharkiv, Ukraine, 61166 \\ E-mail: valeriaaksyuta@gmail.com \\ ORCID ID: 0000-0003-1953-4662
}

\title{
IMPROVEMENT OF ELECTRONIC MONEY ACCOUNTING AT UKRAINIAN ENTERPRISES
}

The popularity of electronic money payments is growing in the modern conditions of digitalization of business processes. The Ukrainian e-money market is at the stage of formation and state settlement. Therefore, it is advisable to clarify the essence of electronic money for accounting purposes, as well as to develop methodological recommendations for their accounting by Ukraine's enterprises. The authors proposed a refined definition of the concept of «electronic money» as an object of accounting, which outlines a lot of emoney legalized in Ukraine. Accordingly, the classification of electronic money for accounting needs has been improved. Electronic payment systems, which have emitted e-money and are represented on the territory of Ukraine, were classified into nine groups. The methodological support for the accounting of transactions with electronic money in the company (as a user and trader) has been improved: additional accounts to synthetic account 33 "Other money» and a fragment of the working plan of accounts has been developed taking into account the types of e-money. Results of scientific research are of practical interest for companies that make settlements with e- money.

Key words: electronic money (e-money), digital money, fiat money, central bank, electronic payment systems, online wallet, internet commerce, electronic money accounting, e-currency.

\section{This work is licensed under a Creative Commons Attribution 4.0 International License} http://creativecommons.org/licenses/by/4.0/

Statement of the problem and its connection with important scientific and practical tasks. The emergence of digital currencies and electronic money was an inevitable stage of computerization and informatization of the global economic space. Virtual payment instruments emerged as a result of the synthesis of finance and IT technologies during the last decade. Digital money is spreading on all continents and is exerting a mounting pressure on the architecture of the international payment system. Digital payment systems WeChat and Alipay are dominant in China. The M-Pesa payment system, operating on the platform of the Safaricom mobile operator, is available in Tanzania and Kenya. The international system of electronic payments PayPal provides online payments between businesses and Internet users in 200 countries of the world. Electronic money systems Perfect Money, Chipknip (Holland), Mondex Internl (Great Britain), Octopus (Hong Kong), WebMoney, Qiwi and YooMoney (Russian Federation), Visa Cash (USA, EU), Geldkarte (Germany), Carta Chiara (Italy), Moneo (France), Proton (Belgium) and others are actively developing and attracting more and more customers. Digital payment systems based on contactless mobile payment technologies are available in Ukraine, including Apple Pay, Android Pay, UnionPay, China UnionPay. Moreover, crypto currencies (Crypto currency) have become a separate type of demanded digital currencies, the distinctive feature of which is the anonymity of the user (Bitcoin and further altcoins - Ethereum, Ripple, Litecoin, Monero, etc.). Various types and forms of digital payment instruments are intensively developing and rapidly spreading, initiating cardinal changes in the global financial system. Looking at the current economic realities, at the beginning of 2021, the European Central Bank is considering the possibility of issuing the electronic euro, and the U.S. Federal Reserve is investigating the possibility of issuing the electronic dollar. In Ukraine, the Government plans to launch a market of virtual assets and introduce the electronic hryvnia (UAH) as a digital national currency. The draft Law «On Virtual Assets» № 3637 of 11.06.2020 [4] is being updated and is under consideration by the Verkhovna Rada. The Ministry of Digital Transformation of Ukraine, which was established in December 2019, implements the state policy on digitalization of economic, political and social spheres in accordance with the development of the information 
society. So, electronic money has already become an economic reality of the modern globalized world and is in the process of further rapid modernization and improvement. The national governments are trying to steamline digitalization processes of the financial system and make them manageable. At this stage, it is the legal registration of electronic payments and the formation of the state mechanism of their management. Legislative provisions on electronic money accounting will be developed at the next stage, after emission of national e-currencies.

Progressively oriented companies in Ukraine are already actively developing online trading, thus making online payments with various types of digital money and faced with the need to keep accounting records of etransactions in compliance with the accounting legislation. At the same time, both the sphere of using electronic money and the sphere of its accounting control are at the stage of changing and metamorphosis not only in Ukraine, but also in all countries of the world. Scientific research on the essence, types and procedure of electronic money accounting must be constantly updated due to the rapid change of the subject of research.

The analysis of the latest publications on the problem. Electronic currencies and variations of their accounting are the subject of extensive research by both Ukrainian and foreign scientists. Mokiyenko T. investigated the time stages of digitalization of the money sphere and also proposed a classification of modern types of electronic money according to four criteria. The publications of Vorontsov E., Derev'yanko S., Semenets A. also contain recommendations for the separation of different types of e-money for accounting purposes. Danilova L. A., Legenchuk S. F., Plisko I. M., Semenets A. P., Shpirko O. M. developed methodological aspects of the accounting reflection of transactions with electronic money, taking into consideration the requirements of accounting legislation of Ukraine. Garbowski M., Drobyazko S. proposed a methodical approach to financial accounting by e-business enterprises operating at the international level [14]. The publication contains suggestions on identifying the place of accounting of an international company to prevent cybercrime.

All of the above-mentioned scientists in their scientific works first investigated the essence and meaning of electronic money, substantiated the author's vision of its definition and types, and only the next step was to formulate recommendations for the accounting of emoney by domestic enterprises. Foreign experts also investigate electronic, digital and virtual money as a new phenomenon of the financial system and propose variants of their classification, methods of regulating and controlling electronic payments on the macro level of the state, the order of accounting and analysis of e- money flow on the micro level of individual companies.

Bech, M., Garrett R., Duffie D. developed different classifications of digital currencies and predicted the appearance of banking digital currencies and adjustable central payment systems [12]. Reiss D. G. explored the types of modern money and concluded that «e-money may be granted a higher status than cash as ICT advances» [19]. Eichengreen B. considers that electronic money is a reality of the information society, and its emergence is an active historical process of development of the world financial system [13].

Baddeley M. described the trends of coexistence electronic money and usual forms of payments (cash and bank transfers) and concluded that it was impossible to completely reject to use of fiat currency in favor of virtual private payment instruments at the current stage of economic development [6].

Anjelina A. conducted a statistical research of subjective perception of electronic money by users and revealed gender and age priorities for payments [5]. Widiyati D., Hasanah N. conducted an online survey, using multiple regression analysis, and established the factors that influence usage of electronic money, such as: Perceived of Benefit and Compatibility, Perceived of Usefulness [21]. Wulandari, D., Soseco T., Narmaditya B. S., analyzed the prevalence of electronic payments among students, establishing the influence of digital awareness on frequency of e-payments [22].

Berentsen A., Schär F. [7], Kahn C. M., Rivadeneyra F., Wong T.-N. [15], have proposed their own conceptual vision of the digital payments sphere in the context of its gradual implementation to the existing banking sector. The experts of state banks of different countries develop algorithms and mechanisms of subordination electronic money to Central Banks (for example, the technical report of the Bank for International Settlements [9], bank working papers by authorship Brunnermeier M.K., James H., Landau J.-P. [8], Tobias A., Mancini-Griffoli T. [20], Zhu Y., Hendry S. [23]). In the opinion of researchers, digitalization of payments will lead to the transformation of international currency relations, to the internationalization of electronic currencies as a means of exchange [23]. Therefore, scientific discussions of foreign scientists are primarily about the essence and types of modern electronic money. Scientists and the banking sector are concerned about the problem of transformation of the global financial system because of implementation of digital currencies into it. The issue of accounting of electronic currencies in the individual countries is a subordinate and secondary to the global problematics described above. Its final decision depends on which types of electronic currencies will be legalized by the world community.

Rawashden A. M. J.researched the methodical support for electronic money accounting in European countries and found that at present the IFRS does not have enough complete comments for the accounting of electronic money [18]. Bernstein L., Breuil R., Bethe Y., Matessych R., Myddlton J., Nydlz B., Humphrey D., Zeff A. developed recommendations on certain aspects of the accounting of e-money in the conditions of their future development and incomplete formation.

As a result, it can be argued that the research of definitions, types, differences in electronic money, as well as the development of methodological recommendations of their accounting are definitely relevant in the context of modern digitalization of business relations and payments. 
Forming of the aims of the research. The aim of the work is to clarify the essence and classification of electronic money for the purposes of their accounting and to develop on this basis methodological recommendations on how to reflect business operations of Ukrainian companies with electronic money in the accounting.

To achieve the goal, the following tasks must be done:

- to investigate the scientific approaches to the definition of e-money;

- to arrange the modern types of electronic money according to the list of classification features;

- to describe the current legislation of Ukraine on the technique of conduct and accounting for electronic money as of 2021;

- to propose the procedure of reflecting e-money payments in the accounting of domestic enterprises, in compliance with accounting standards and current legislation in the field of digital commerce;

- to substantiate the trends in the development of electronic payment instruments and the related prospects for improving national accounting standards in terms of e-money settlements.

Giving an account of the main results and their substantiation. Before developing methodological recommendations on e-payments accounting, it is necessary, firstly, to clarify the concept of «electronic money» as a subject of accounting and, secondly, to identify many types of e-money, which are a legal means of payment on the territory of Ukraine.

Traditionally, cash exists in a cash form (banknotes, coins) and in a non-cash form of payment (bank account records). Individuals and legal entities make payments by cash or by bank transfer from one current account to another. In the latter case, paper, electronic or other data media are used to transfer. Electronic money, which has recently appeared, performs the function of a means of payment in the same way as cash and non-cash money. However, e-money is not stored on the bank accounts, but on the digital devices.

In addition, cash and non-cash money are the national currencies of individual countries. The countries of the world emit national currencies, which always have a physical media (banknotes, coins), manage their circulation and are a guarantor of their value. Instead, the issuer of electronic money can be a private company, which undertake to convert it into the selected currency at the request of e-money users. Electronic money is beyond the sphere of state or international regulation now. The difference between e-money and traditional forms of money (cash and non-cash money) is the reason of scientific debate about its essence. Electronic money is able to fully perform the following functions of money: measure of value, means of exchange, means of payment and means of accumulation [6]. E-money is not yet able to assume the function of world money, but over time, the actions of the central banks of the countries may lead to the acquisition of this function. Scientists are debating about the essence of electronic money, because they have different interpretations of its place in relation to the cash and noncash money.

After studying the works of domestic and foreign experts $[8 ; 12 ; 13 ; 18-20 ; 23]$ and Ukrainian legislation $[1-4 ; 16 ; 17]$ as well as the European Union Directives $[10 ; 11]$ regarding the investigated matter, the authors concluded that the modern scientific understanding of the essence of the concept of «electronic money» can be grouped into four approaches (Table 1).

Table 1

Modern approaches to defining the concept of «electronic money»*

\begin{tabular}{|l|l|l|}
\hline \multicolumn{1}{|c|}{$\begin{array}{c}\text { Approach to the essence of } \\
\text { electronic money }\end{array}$} & \multicolumn{1}{|c}{ Explanation } & \multicolumn{1}{|c|}{ The adherents of the approach } \\
\hline $\begin{array}{l}\text { Approach 1. Electronic } \\
\text { money is a kind of non-cash } \\
\text { money that have acquired a } \\
\text { dematerialized, electronic } \\
\text { embodiment }\end{array}$ & $\begin{array}{l}\text { This approach is valid only for electronic } \\
\text { money, the emmiters of which are bank in- } \\
\text { stitutions. In this case, the real value of } \\
\text { money secured by the banking system takes } \\
\text { an electronic form. E-money, issued by pri- } \\
\text { vate companies, is not actually secured. }\end{array}$ & $\begin{array}{l}\text { Bank of International Settlements, } \\
\text { European Central Bank, } \\
\text { European Commission (in the re- } \\
\text { ports on e-money of the banks- } \\
\text { emitters); Savluk M. (2004), } \\
\text { Kravchuk V. (2012) }\end{array}$ \\
\hline $\begin{array}{l}\text { Approach 2. Electronic } \\
\text { money is a unit of value and } \\
\text { new electronic payment } \\
\text { methods for current pay- } \\
\text { ments of goods and services } \\
\text { consumers }\end{array}$ & $\begin{array}{l}\text { The approach focuses on the performance of } \\
\text { e-money function of a measure of value, a } \\
\text { means of circulation, a means of payment } \\
\text { but ignores the problem of ensuring their } \\
\text { value. The authors identify e-money with an } \\
\text { innovative payment instrument of today. }\end{array}$ & $\begin{array}{l}\text { Rawashden A. M. J. (2018) [18], } \\
\text { Batrakova T. (2018), } \\
\text { Volyanik G. (2015), } \\
\text { Radionova I. (2011), } \\
\text { Ivasiv B. (2011), } \\
\text { Platonov Y. (2002) }\end{array}$ \\
\hline $\begin{array}{l}\text { Approach 3. Electronic } \\
\text { money is a cash obligation } \\
\text { of the issuer, which is per- } \\
\text { formed in a cash or non-cash } \\
\text { form }\end{array}$ & $\begin{array}{l}\text { Electronic money is a requirement for the } \\
\text { issuer, which is stored on an electronic de- } \\
\text { vice and is accepted as a means of payment } \\
\text { by other legal entities and individuals. The } \\
\text { approach is official for financial institutions } \\
\text { of the EU, USA, Ukraine. }\end{array}$ & $\begin{array}{l}\text { Airective 2009/110/EC of the Eu- } \\
\text { ropean Parliament and of the Coun- } \\
\text { cil [10]; Uniform Payment Services } \\
\text { Act of the United States\$ } \\
\text { Regulation on Electronic Money in } \\
\text { Ukraine № 481 [2]; Kahn C., Tobi- } \\
\text { as A., Mancini-Griffoli T. (2019) } \\
\text { [20], Rivadeneyra F. (2019) [15], } \\
\text { Alekseenko M. (2013) }\end{array}$ \\
\hline
\end{tabular}


Continue of table 1

\begin{tabular}{|l|l|l|}
\hline \multicolumn{1}{|c|}{$\begin{array}{c}\text { Approach to the essence of } \\
\text { electronic money }\end{array}$} & \multicolumn{1}{|c|}{ Explanation } & \multicolumn{1}{c|}{ The adherents of the approach } \\
\hline $\begin{array}{l}\text { Approach 4. Electronic } \\
\text { money is a special form of } \\
\text { cash (third), which is in the } \\
\text { formative stage and differs } \\
\text { from cash and non-cash } \\
\text { money }\end{array}$ & $\begin{array}{l}\text { In the future, e-money could become the } \\
\text { third form of money, on the same level as } \\
\text { cash and non-cash money, acquiring the } \\
\text { functions of global money. This will happen } \\
\text { if the central banks of the world accept na- } \\
\text { tional electronic currency (e-euro, e-dollar, } \\
\text { e-yuan, etc.). }\end{array}$ & $\begin{array}{l}\text { Skorobogatova V. (2012), Yanchev } \\
\text { A. (2014), Shishkova N. (2017), } \\
\text { Michengreen T., Priydak T. (2019), } \\
\text { nermeier M. , James H., Landau J.- } \\
\text { P. (2019) [8] }\end{array}$ \\
\hline
\end{tabular}

* Developed by the authors

Central banks of different countries consider emoney within the legislative framework defined by state legislation. Thus, according to Article 15 of the Law of Ukraine «On Payment Systems and Money Transfer», only a bank can issue electronic money. Therefore, the banking sector often ignores private issuers in its reports narrowing the concept of e-money to the electronic form of non-cash funds available in banks. EC Directive 2009/110/EC criticizes this approach, stating that the definition of e-money «should be wide enough to avoid hampering technological innovation and to cover not only all the electronic money products available today in the market but also those products which could be developed in the future» [11].

Many scholars focus on performing by the electronic money the functions of a unit of cost and a payment instrument (approach 2 of Table 1). However, the current legislation of the EU, the U.S. and Ukraine defines the definition of e-money within the third approach (Table 1). Thus, according to the EC Directive, «electronic money means electronically, including magnetically, stored monetary value as represented by a claim on the issuer which is issued on receipt of funds for the purpose of making payment transactions and which is accepted by an individual or legal person except the electronic money issuer» [11]. Financial legislation of Ukraine interprets electronic money as units of value stored on an electronic device, is accepted as a means of payment by other persons than the person who issued them, and is a monetary obligation of this person, which is performed in the cash or non-cash form [17]. Furthermore, according to Ukrainian Accounting Standards № 1 «General requirements for financial reporting», money is a cash, funds on the bank accounts and demand deposits, - electronic money is not in this list. The definitions of the EU and Ukraine focus on the issuer's obligation to convert e-money into cash or non-cash at the user's request. It solves the problem of ensuring the value of electronic payment instruments. Scientists, who hold to Approach 4 (Table 1), define emoney as a new third form of money, which is currently developing and is gradually formed. Their expectations will come true if the central banks implement the stated intentions concerning emission of national electronic currencies. This will radically change the content, order of usage and accounting of e-money.

After investigating the progressive views of scientists on the essence of e-money, we can assert that the following is not electronic money:
- digital devices of access to the bank account (bank payment cards with microprocessor or magnetic page);

- transactions of online banking (using the current, deposit, credit bank accounts in fiat national or foreign currencies); fuel cards);

- prepaid single-purpose cards (gift, telephone or

- virtual local currencies of certain Internet portals (e.g., online gaming currencies - «arctic thalers», «kalganids», etc.);

- crypto currency (fully anonymous transactions are done in an autonomous decentralized payment system, using blockchain technology, acyclic graph, consensus registry).

Laws «About currency and currency transactions» [1], «About payment systems and money transfer in Ukraine» [3], and also Regulation on Electronic Money [2], adopted by the National Bank, regulate the order of issuance, distribution, conversion, settlement, and storage of electronic money in digital wallets in Ukraine.

The authors analyzed scientific works of Ukrainian (Mokiyenko T., Vorontsova E., Derev'yanko S., Koryagin M., Semenets A.) and foreign scientists (Bech, M., Garrett R., Duffie D. [12], Reiss D. G. [19], Tobias A., Mancini-Griffoli T. [20]) about directions of classification and relevant types of electronic currencies. In addition, the authors reviewed the features of popular electronic payment systems, which emit e-money and service the payments with them. As a result of this research, Table 2 was created.

On the one hand, this table demonstrates four main criteria for the classification of e-money, important for the Ukrainian user. On the other hand, the table describes at the same time the distinctive features of each of the 17 electronic payment systems whose electronic money is used or can potentially be used for e-payments on the territory of Ukraine.

Modern payment systems that emit electronic money and service its usage are technologically based on either Internet networks or smart cards (criterion 1 of Table 2). Some electronic payment systems require mandatory identification of user, while others allow anonymous transfers (criterion 2 of Table 2).

Electronic fiat money expressed in the national currency of the country of origin is part of the payment system of a certain state, and its emission and circulation are carried out in compliance with the state legislation. 
Table 2

Classification of electronic money used by individuals and legal entities of Ukraine as of 2021*

\begin{tabular}{|c|c|c|c|c|c|c|c|c|c|}
\hline \multirow{3}{*}{$\begin{array}{c}\text { The name of the electronic } \\
\text { payment system that emit e- } \\
\text { money and services their pay- } \\
\text { ment }\end{array}$} & \multicolumn{9}{|c|}{ Areas of electronic money classification } \\
\hline & \multicolumn{2}{|c|}{$\begin{array}{l}\text { 1. by the shape } \\
\text { of the carrier }\end{array}$} & \multicolumn{2}{|c|}{$\begin{array}{l}\text { 2. by anonym- } \\
\text { ity }\end{array}$} & \multicolumn{2}{|c|}{$\begin{array}{l}\text { 3. by the level } \\
\text { of the emitter }\end{array}$} & \multicolumn{3}{|c|}{$\begin{array}{l}\text { 4. by permission in } \\
\text { Ukraine }\end{array}$} \\
\hline & 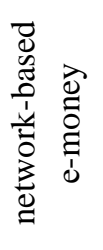 & 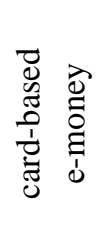 & 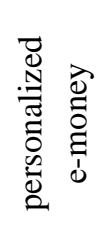 & 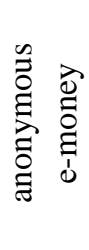 & 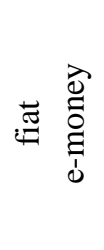 & 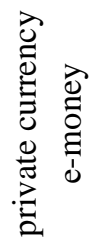 & 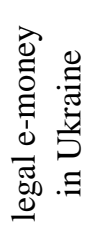 & 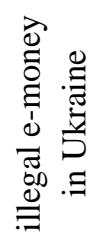 & 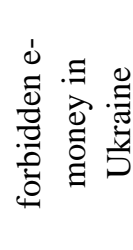 \\
\hline PayPal & $\checkmark$ & & & $\checkmark$ & $\checkmark$ & & & $\checkmark$ & \\
\hline Skrill & $\checkmark$ & & $\checkmark$ & & & $\checkmark$ & $\checkmark$ & & \\
\hline Epayments & $\checkmark$ & & & $\checkmark$ & & $\checkmark$ & & $\checkmark$ & \\
\hline Payeer & $\checkmark$ & & & $\checkmark$ & & $\checkmark$ & & $\checkmark$ & \\
\hline Perfect Money & $\checkmark$ & & & $\checkmark$ & & $\checkmark$ & & $\checkmark$ & \\
\hline EasyPay & $\checkmark$ & & & $\checkmark$ & & $\checkmark$ & & $\checkmark$ & \\
\hline PayRun & $\checkmark$ & & $\checkmark$ & & & $\checkmark$ & $\checkmark$ & & \\
\hline WebMoney & $\checkmark$ & & & $\checkmark$ & & $\checkmark$ & & & $\checkmark$ \\
\hline QIWI & $\checkmark$ & & & $\checkmark$ & & $\checkmark$ & & & $\checkmark$ \\
\hline Yandex money & $\checkmark$ & & & $\checkmark$ & & $\checkmark$ & & & $\checkmark$ \\
\hline Google Pay & $\checkmark$ & & $\checkmark$ & & & $\checkmark$ & $\checkmark$ & & \\
\hline Facebook Pay & $\checkmark$ & & $\checkmark$ & & & $\checkmark$ & $\checkmark$ & & \\
\hline Virtual digital card of Visa & & $\checkmark$ & $\checkmark$ & & $\checkmark$ & & $\checkmark$ & & \\
\hline $\begin{array}{l}\text { Virtual digital card of Mas- } \\
\text { terCard }\end{array}$ & & $\checkmark$ & $\checkmark$ & & $\checkmark$ & & $\checkmark$ & & \\
\hline $\begin{array}{l}\text { Virtual digital card of National } \\
\text { system of mass electronic } \\
\text { payments («Prostir», Ukraine) }\end{array}$ & & $\checkmark$ & $\checkmark$ & & $\checkmark$ & & $\checkmark$ & & \\
\hline $\begin{array}{l}\text { Virtual digital card of Ukraini- } \\
\text { an banks (Global Money, } \\
\text { Maxi, NovaPay, Alfa-Money, } \\
\text { Electrum) }\end{array}$ & & $\checkmark$ & $\checkmark$ & & $\checkmark$ & & $\checkmark$ & & \\
\hline
\end{tabular}

\section{* Developed by the authors}

For example, the international system PayPal issues fiat e-money, operating under U.S. financial law. MPesa is the fiat electronic money of Kenya and Tanzania. In our country, they are represented as virtual digital cards issued by Ukrainian banks, which have received a special permission of the NBU on the basis of Visa, MasterCard, and are virtual e-money (for example, e-money from Oshchadbank, Megabank PJSC, Raiffeisen Bank Aval) or proprietary software (e.g. Maxi from Tascombank PJSC, Electrum from Ukrgazbank JSC, GlobalMoney from Alliance Bank PJSC) [2]. It should be noted that most of the electronic currencies on the current digital currency market are issued by private issuers (criterion 3 of Table 2).

Technological form, anonymity level and content of electronic money in sum determine their place in the financial sector of Ukraine (criterion 4 in Table 2). According to the Regulation on Electronic Money, in Ukraine only fiat physical electronic money issued by licensed resident banks or non-resident issuers listed in the Register of Payment Systems [2] (legal e-money in
Ukraine, criterion 4 of Table 2) may be legally in circulation. The system of contactless payment by Google Pay phone is legalized in our country and is spreading rapidly. The Facebook Pay payment service has been authorized by the NBU and operated on the territory of Ukraine since August 2020. However, the international payment systems PayPal, Epayments, Payeer, EasyPay have not passed the procedures of legitimization by the NBU, so they cannot operate fully in the financial market of Ukraine. A separate group is Russian private e-payment systems WebMoney, QIWI, Yandex money, which are subject to Ukraine sanctions, so their use is banned.

The clustering of e-money and appropriate payment systems - issuers described by the authors in Table 2 helps to identify types of electronic money that can be converted and accepted as a means of payment by domestic companies, according to the legislation of Ukraine (Fig. 1). Resident banks by NBU license issue electronic money nominated in $\mathrm{UAH}$, which is considered a type of national currency. 
Non-bank financial institutions can be only intermediary agents, providing digital payment distribution services. Non-resident issuer emits electronic money nominated in foreign currency units and (or) bank metals that are nominated as a type of foreign currency (Art. 1 of the Law «About currency and currency transactions» [1]). In both cases, there is mandatory identification and verification of users. Only the above-mentioned types of electronic money are the subject of accounting of Ukrainian companies. The use of other e-money is forbidden.

Electronic money, which is allowed to be used by

Ukrainian resident business entities

Electronic money issued by Ukrainian banks, which received a special permission of the NBU and were included in the Register of Payment Systems of Ukraine
Electronic money, non-resident issuers of which are registered in the Register of Payment Systems of Ukraine

Electronic money in national currency

\section{Lectronic money in national currency} ing payment system such as: Visa, MasterCard (foreign), Prostir (domestic) payment systems e-money from Oshchadbank JSC, Megabank PJSC, Raiffeisen Bank Aval JSC, others
Ukrainian banks' e-money us-
Ukrainian banks' e-money using their own payment systems - Maxi from Tascom Bank PJSC, Electrum from Ukrgazbank JSB, GlobalMoney from Alliance Bank JSC, Alfa-Money from AlfaBank PJSC; others

\section{Fig. 1. Types of electronic money, which the domestic enterprises have the right to use as payment instruments on the territory of Ukraine, as of 2021* \\ * Developed by the authors}

Thus, as of the beginning of 2021, the following definition of the concept of «electronic money» is proposed for the purposes of the accounting of domestic companies, in compliance with Ukrainian legislation. This is a financial obligation of the e-money issuer, registered with the Register of Payment Systems of Ukraine, to the holder, which:

1) is an electronic record, which contains information about a certain amount of value, secured by cryptographic algorithms and stored on a digital device;

2 ) is accepted as a means of payment by individuals and legal entities, others, than the issuer;

3 ) is executed by the issuer at the request of the user - a legal entity in non-cash form in national currency.
Accounting of electronic money of the enterprise is completely regulated by the Law of Ukraine on Accounting and the National Accounting Standards. In addition, the current procedure of e-money accounting is determined by the legal interpretation of e-money, formed by legislation $[1 ; 2 ; 3 ; 16 ; 17]$. For accounting purposes, electronic money classified as «Other money» because it is a monetary obligation that can be converted into cash and non-cash money. Accordingly, the Schedule of Accounts and Instructions provide sub-account 335 «Electronic money nominated in the national currency» for the accounting of the company's e-currencies. Table 3 shows the types of operations for sub-account 335.

Table 3

Current procedure for accounting of electronic money nominated in national currency*

\begin{tabular}{|c|c|c|c|}
\hline \multirow{2}{*}{ Business transaction } & \multirow{2}{*}{ Documentation } & \multicolumn{2}{|c|}{ Accounting } \\
\hline & & Debit & Credit \\
\hline \multicolumn{4}{|c|}{ Enterprise as a purchaser that makes payment with e-money (electronic wallet of the user - business entity [2]) } \\
\hline $\begin{array}{l}\text { Opening of electronic wallet for purchasing e-money } \\
\text { and making payments for the needs of the business }\end{array}$ & \multicolumn{3}{|c|}{$\begin{array}{l}\text { Agreement with the issuing bank for providing services for } \\
\text { e-money transactions. Opening of the electronic user's wallet }\end{array}$} \\
\hline $\begin{array}{l}\text { National currency was transferred from the current } \\
\text { account for obtaining e-money }\end{array}$ & \multirow{4}{*}{$\begin{array}{l}\text { application for the purchse of e-money; } \\
\text { payment order; statement from the cur- } \\
\text { rent account of the bank; statement from } \\
\text { the e-money system; act of acceptance- } \\
\text { transfer of e-money; accounting refer- } \\
\text { ence }\end{array}$} & 333 & 311 \\
\hline Accrued and deducted commission of the issuing & & 92 & 685 \\
\hline bank for the & & 685 & 333 \\
\hline The e-money credited to the e-wallet & & 335.1 & 333 \\
\hline
\end{tabular}


Continue of table 3

\begin{tabular}{|c|c|c|c|}
\hline \multirow{2}{*}{ Business transaction } & \multirow{2}{*}{ Documentation } & \multicolumn{2}{|c|}{ Accounting } \\
\hline & & Debit & Credit \\
\hline $\begin{array}{l}\text { Transferred payment for goods (works, services) by } \\
\text { e-money }\end{array}$ & $\begin{array}{l}\text { supplier's account, receipt from the e- } \\
\text { money system }\end{array}$ & $\begin{array}{c}631 \\
(371)\end{array}$ & 335.1 \\
\hline $\begin{array}{l}\text { The accountable person paid for goods (works, ser- } \\
\text { vices) using the company's electronic wallet }\end{array}$ & $\begin{array}{l}\text { report on the use of funds issued for the } \\
\text { report }\end{array}$ & 372 & 335.1 \\
\hline \multicolumn{4}{|c|}{ Enterprise as a seller, which accepts payment in e-money (e-wallet of the trader [2]) } \\
\hline $\begin{array}{l}\text { Opening of an electronic wallet for accepting elec- } \\
\text { tronic money from users as payment for goods, works } \\
\text { and services }\end{array}$ & \multicolumn{3}{|c|}{$\begin{array}{l}\text { Agreement with the issuing bank on the provision of ser- } \\
\text { vices for e-money transactions. Opening of the electronic } \\
\text { merchant's wallet }\end{array}$} \\
\hline $\begin{array}{l}\text { E-money received from the buyer as payment for } \\
\text { goods (works, services) }\end{array}$ & $\begin{array}{l}\text { The receipt from the e-money system; } \\
\text { invoice; delivery note (act of performed } \\
\text { works, rendered services) }\end{array}$ & 335.2 & $\begin{array}{l}361 \\
(681)\end{array}$ \\
\hline $\begin{array}{l}\text { The e-money has been presented to the issuing bank } \\
\text { for repayment }\end{array}$ & \multirow{4}{*}{$\begin{array}{l}\text { application for repayment of e-money; } \\
\text { extract from the e-money system; extract } \\
\text { from the bank's current account; act of } \\
\text { acceptance-transfer of e-money }\end{array}$} & 377 & 335.2 \\
\hline \multirow{2}{*}{$\begin{array}{l}\text { Accrued and deducted commission of the issuing } \\
\text { bank for repayment(exchange) of e-money }\end{array}$} & & 92 & 685 \\
\hline & & 685 & 311 \\
\hline $\begin{array}{l}\text { National currency received from the conversion of e- } \\
\text { money was deposited on the current bank account }\end{array}$ & & 311 & 377 \\
\hline
\end{tabular}

$$
\text { * Developed by the authors }
$$

According to the Regulation on Electronic Money in Ukraine [2], an enterprise can use electronic money either as a user (to buy goods, works or services) or as a merchant (to receive e-money from buyers). For each case, it is necessary to have a separate electronic wallet (EW) - EW of the user and EW of the merchant [2]. In the author's opinion, it is advisable to include the analytical accounts for these particular wallets in sub-account 335. For example, 335.1 «Electronic Wallet for Purchasing» (User's EW) and 335.2 «Electronic Wallet for Sales» (Merchant's EW) (Table 3).

Items 5, 6 of Section 4 of the Regulation on Electronic Money in Ukraine [2] limit the actions of the company with e-money according to the list of operations presented in Table 3. Besides, business entities - payers of the Unitary tax are suspended from payments with electronic money because Article 291 of the Tax Code of Ukraine defines that they have to make payments only in cash or non-cash forms.

The company (as a holder) has the right to use emoney in foreign currency for payments in favour of nonresidents, issued by a foreign agency, registered in the Register of Payment Systems of Ukraine [2]. Also, the company (as a trader) is allowed to accept electronic money in foreign currencies from foreign buyers, but under certain conditions:

1) issuer of e-money is a non-resident registered in the Register of Payment Systems of Ukraine;

2) e-money in foreign currencies received on the electronic wallet of the trading company must be immediately repaid, i.e. converted into non-cash money and deposited to the current account in a Ukrainian bank [2].

In addition, on the electronic wallet all received foreign earnings are converted into a non-cash without being leaved on the balance. However, e-money in foreign currencies can be stored on the user's e-wallet and can be used to pay for goods or convert them into other legal e-money [2]. It is considered advisable to use a separate sub-account for the accounting of electronic money nominated in foreign currencies.

The law on «About currency and currency transactions» establishes that electronic money nominated in monetary units of foreign countries and (or) bank metals is foreign currency [1]. Therefore, the company must register e-money in foreign currencies in accordance with the rules set out in the UAS (Ukrainian Accounting Standards) 21 «Influence of Changes in Foreign Exchange Rates». Funds accounted for to the e-wallet account from a non-resident issuer should be accounted simultaneously both in foreign currency and UAH equivalent (at the NBU exchange rate on the date of the transaction). Surplus of e-money in foreign currencies on the e-wallet is a monetary balance sheet item and is subject to recalculation both on the date of payment from this wallet, and on the balance sheet date, using the corresponding NBU exchange rate. Exchange rate differences that arise during the revaluation of foreign currency at ewallets, are necessary to register on sub-accounts 714 «Income from operational exchange rate differences» and 945 «Losses from operational exchange rate differences», if transfers from e-wallet are made for the needs of operational activity. If e-money was used for purchasing investment activities (e.g., for the acquisition on inventory items to upgrade fixed assets), then exchange rate differences are accounted for on sub-accounts 744 «Income from non-operating exchange rate differences» and 974 «Losses from non-operating exchange rate differences». Table 4 contains examples of foreign currency transactions of the company - electronic wallet user.

Therefore, the legislators identified electronic money, nominated in foreign currency and issued by a non-resident, with fiat foreign currency, thus regulating the accounting of such e-money by UAS 21. But, it leaves the matter of NBU exchange rate unresolved. 
Table 4

Current procedure for accounting of electronic money nominated in foreign currencies at the enterprise the user of the e-wallet*

\begin{tabular}{|c|c|c|c|}
\hline \multirow{2}{*}{ Business transaction } & \multicolumn{2}{|c|}{ Accounting } & \multirow{2}{*}{ Sum } \\
\hline & Debit & Credit & \\
\hline $\begin{array}{l}\text { 26.03.2021. Foreign currency was transferred from the current currency ac- } \\
\text { count of a non-resident issuer for obtaining e-money in foreign currency/ } \\
\text { NBU course } 27,9698 \text { UAH/USD } \\
\text { UAH equivalent }=1000 \mathrm{USD} \cdot 27,9698 \mathrm{UAH} / \mathrm{USD}=27969,80 \mathrm{UAH}\end{array}$ & 334 & 312 & $\frac{1000 \mathrm{USD}}{27969,80 \mathrm{UAH}}$ \\
\hline \multirow{2}{*}{$\begin{array}{l}\text { 26.03.2021. Accrued and deducted commission of nonresident issuer or the } \\
\text { purchase of e-money in foreign currency (conditionally, the commission is } \\
1.2 \% \text { ). Commission }=1000 \mathrm{USD} \cdot 1,2 \%=12 \mathrm{USD} \\
\mathrm{UAH} \text { equivalent }=12 \mathrm{USD} \cdot 27,9698 \mathrm{UAH} / \mathrm{USD}=335,64 \mathrm{UAH}\end{array}$} & 92 & 685 & \multirow{2}{*}{$\frac{12 \text { USD }}{335,64 \mathrm{UAH}}$} \\
\hline & 685 & 334 & \\
\hline $\begin{array}{l}\text { 26.03.2021. E-money in foreign currencies is deposited on the user's elec- } \\
\text { tronic wallet (as calculated by the commission) }\end{array}$ & $336^{*}$ & 334 & $\frac{988 \mathrm{USD}}{27634,16 \mathrm{UAH}}$ \\
\hline $\begin{array}{l}\text { 29.03.2021. Transfers of payment in e-money in foreign currency to non- } \\
\text { resident supplier for goods (works, services) NBU course 29.03.2021. - } \\
27,9679 \mathrm{UAH} / \mathrm{USD} \text {. } \\
\text { UAH equivalent }=300 \mathrm{USD} \cdot 27,9679 \mathrm{UAH} / \mathrm{USD}=8390,37 \mathrm{UAH}\end{array}$ & $\begin{array}{c}632 \\
(371)\end{array}$ & 336 & $\frac{300 \text { USD }}{8390,37 \text { UAH }}$ \\
\hline $\begin{array}{l}\text { 29.03.2021. Accrued a negative exchange rate difference on e-money nomi- } \\
\text { nated in foreign currency, converted into payment for goods. Exchange rate } \\
\text { difference }=(27,9679-27,9698) \cdot 300 \text { USD }=-0,57 \text { UAH }\end{array}$ & 945 & 336 & $0,57 \mathrm{UAH}$ \\
\hline $\begin{array}{l}\text { 30.03.2021. The accountable person paid to the supplier }- \text { the nonresident the } \\
\text { goods (works, services) by means of an electronic wallet of the enterprise } \\
\text { NBU course } 30.03 .2021 .-27,9694 \text { UAH/USD } \\
\text { UAH equivalent }=400 \text { дол } \cdot 27,9694 \text { UAH/USD }=11187,76 \text { UAH }\end{array}$ & 372 & 336 & $\frac{400 \mathrm{USD}}{11187,76 \mathrm{UAH}}$ \\
\hline $\begin{array}{l}30.03 .2021 \mathrm{p} \text { Accrued a negative exchange rate difference on e-money nom- } \\
\text { inated in foreign currency, converted into payment for goods. Exchange rate } \\
\text { difference }=(27,9694-27,9698) \cdot 400 \mathrm{USD}=-0,16 \mathrm{UAH}\end{array}$ & 945 & 336 & $0,16 \mathrm{UAH}$ \\
\hline $\begin{array}{l}31.03 .2021 \mathrm{p} \text {. Revaluated remnant of electronic money, denominated in for- } \\
\text { eign currency, as of the balance date. NBU course } 31.03 .2021-27,8852 \\
\text { UAH/USD } \\
\text { Exchange rate difference }=(27,8852-27,9698) \cdot 288 \mathrm{USD}=-24,37 \mathrm{UAH}\end{array}$ & 945 & 336 & $24,37 \mathrm{UAH}$ \\
\hline
\end{tabular}

Note: subaccount 336 «Electronic money nominated in foreign currencies» (author's proposal). Conditionally, there is no commission for the transfer of e-money from the e-wallet.

* Developed by the authors

The National Bank sets the official exchange rates for the currencies presented in the Currency Classifier on a daily basis. If account units of the electronic payment system are identified with these currencies (dollar, euro), then the application of the NBU exchange rate is understandable. However, if the foreign payment system issues alternative units (e.g.: Web Money title units (characters), E-Gold), the NBU does not give them UAH value. Today the Register of Payment Systems does not include non-resident entities with unique e-money units. However, in case of verification of such payment system in Ukraine there will be a problem of legislative regulation of such e-money payments.

To improve the electronic money accounting at domestic enterprises under current conditions it is recommended to: open synthetic account 33 «Other funds» sub-account 336 «Electronic money nominated in foreign currencies»; use analytical accounts to subaccounts 335 and 336 for accounting classification of the company's electronic money: a) for the purpose of the electronic wallet (for purchases or for the receipt of trade revenue); b) by the issuer of e-money; c) for the currency of emoney). The recommendations are illustrated in Table 5.
Observing the current processes of digitalization of economic and social life, we can confidently predict the further strengthening of electronic currencies and the popularization of online payments. In Ukraine, the prospect of e-payments is related to their dissemination, the legalization of new foreign payment systems and the legislative authorization of additional opportunities for the use of e-money by economic entities. Potentially, ewallets can be used not only for online payments, but also for settlements with hired employees, for deposit and credit operations, for investing in business projects. Ewallets have cash-back service and referral programs. However, these possibilities are still legally forbidden for enterprises.

With the gradual modernization of the state regulation of emission and use of electronic money, the updating of the accounting legislation of e-payments will take place. In the author's opinion, firstly sub-account 336 «Electronic money nominated in foreign currencies» will be added to the Plan of Accounts, and the procedure of determining the $\mathrm{UAH}$ equivalent and the exchange rate differences will be clarified. 
Fragment of the Work Plan for the E-money Accounting *

\begin{tabular}{|c|c|c|c|c|}
\hline $\begin{array}{l}\text { Synthetic } \\
\text { accounts }\end{array}$ & Subacounts & \multicolumn{3}{|c|}{ Analytical accounts } \\
\hline $\begin{array}{l}\text { Accounts of } \\
\text { the } 1^{\text {st }} \text { order }\end{array}$ & $\begin{array}{l}\text { Accounts of the } \\
\text { 2nd order }\end{array}$ & Accounts of the 3 rd order & $\begin{array}{l}\text { Accounts of } \\
\text { the } 4 \text { th order }\end{array}$ & Accounts of the 5 th order \\
\hline \multirow{4}{*}{$\begin{array}{l}33 \ll \text { Other } \\
\text { funds» }\end{array}$} & \multirow{2}{*}{$\begin{array}{l}335 \text { «Electronic } \\
\text { money nomi- } \\
\text { nated in the } \\
\text { national curren- } \\
\text { cy» }\end{array}$} & $\begin{array}{l}335.1 \text { «A UAH electronic wallet } \\
\text { for purchases». }\end{array}$ & $\begin{array}{l}\text { By e-money } \\
\text { issuers }\end{array}$ & - \\
\hline & & $\begin{array}{l}335.2 \text { «A UAH electronic wallet } \\
\text { for sales». }\end{array}$ & $\begin{array}{l}\text { By e-money } \\
\text { issuers }\end{array}$ & - \\
\hline & \multirow{2}{*}{$\begin{array}{l}336 \text { «Electronic } \\
\text { money nomi- } \\
\text { nated in foreign } \\
\text { currencies» }\end{array}$} & $\begin{array}{l}336.1 \text { «Currency electronic wal- } \\
\text { let for purchasing» }\end{array}$ & $\begin{array}{l}\text { By e-money } \\
\text { issuers }\end{array}$ & $\begin{array}{l}\text { By foreign currency in } \\
\text { which e-money is nomi- } \\
\text { nated }\end{array}$ \\
\hline & & $\begin{array}{l}336.2 \text { «Currency electronic wal- } \\
\text { let for sales» }\end{array}$ & $\begin{array}{l}\text { By e-money } \\
\text { issuers }\end{array}$ & $\begin{array}{l}\text { By foreign currency in } \\
\text { which e-money is nomi- } \\
\text { nated }\end{array}$ \\
\hline
\end{tabular}

* Developed by the authors

When companies will be legally allowed to use e-money in new ways, accounting standards will have explanation of accounting of such transactions.

If the transition of the global financial system to the national electronic currencies becomes a reality, emoney issued by the central banks of the states will acquire the status of the third form of money, on the same level as the existing cash and non-cash currencies. In this case, the legal framework of the technique of ecalculations and their accounting will be radically changed. For the described changes the proposals of Neskhodsky I., Skorobogatova V., Yanchev A., to include a new account 32 «Electronic money» for e-money accounting in the chart of accounts will be appropriate, or Olifirova's Y. recommendations to introduce the subaccount 315 «Electronic money» to account 31 «Bank accounts». At the present time, these recommendations are inconsistent with the law.

Conclusions and prospects of the further investigations.The work includes a solid investigation of the views of Ukrainian and foreign scholars on the economic contents, legal status, types of digital money as to key issues of their use, state regulation and the result of expansion. This article examines electronic payment systems presented on the territory of Ukraine. Their classification was carried out according to four characteristic features, which allowed us to identify e-money that domestic enterprises have the right to legally use in business. Soundly the presence of two main types of e-money legalized in Ukraine was substantiated: e-money nominated in national currency and e-money nominated in foreign currency. This made it necessary to add the subaccount 336 to the current Schedule of Accounts. Analytical accouns to sub-accounts 335 and 336 are proposed to be maintained to detail the movement of e-money of the enterprise by types of electronic wallets, by issuers of these wallets, by the currency in which e- money is nominated.

The current procedure of settlement accounting of domestic enterprises electronic money nominated in national and foreign currencies has been described in detail. Examples of accounting transactions for accounting of business transactions on the electronic wallet of the user and merchant have been given. The necessity of clarifying the Ukrainian accounting legislation in terms of specifying the UAH equivalent of e-money denominated in foreign currencies has been explained. The tendencies of further spreading of electronic payments in Ukraine and related changes in the legislation have been substantiated.

Methods of observation, theoretical generalization and grouping were used to study the modern market of electronic money and the corresponding legal framework, as well as to clarify the conceptual apparatus. The graphical method is used for schematic visualization of the study's general provisions. The methods of scientific abstraction, induction and deduction were used to develop recommendations for improvement of e-settlement accounting of Ukrainian enterprises.

The scientific novelty of the obtained results lies in the following:

- The concept of «electronic money» as an object of accounting was further developed; the suggested author's definition allows us to define a number of emoney that are legally allowed to be used by business entities;

- The classification of electronic money for accounting purposes has been improved. The affiliation of electronic payment systems, which have emitted e-money and are represented on the territory of Ukraine have been identified, to nine groups (network-based or card-based; personalized or anonymous; fiat e-money or private currency; legal, illegal or forbidden e-money in Ukraine), the following four classification criteria (form of wear, anonymity, issuer rating) are used to determine the level of the content, permissibility in Ukraine. The result is now presented in the analytical table, which allowed us to describe many types of electronic currencies that domestic enterprises have the right to use as payment instruments on the territory of Ukraine;

- The methodological support for the accounting of transactions with electronic money in the company (as 
a user and trader) has been improved: additional accounts of orders 2-5 to synthetic account 33 «Other money» and a fragment of the working plan of accounts has been developed taking into account the types of e-money.

The conducted research is of practical interest for financial managers and accounting managers of domestic progressive companies that make settlements with electronic money. Business entities can use the recommendations to improve the working plan of the bank accounts, as well as examples of transactions with e-money nominated in national and foreign currencies have been provided.

The modern world is sinking into virtual space. Electronic money is an important tool for digitalization of economic and social life. The importance of electronic settlements will inevitably grow, and the scope of application will expand, perhaps even to the point of achieving the e-money function of world money on the interstate level. Increasingly, all new participants of electronic payments will be admitted to the financial market of Ukraine, first of all, popular abroad electronic payment systems (like PayPal). It is expected that domestic enterprises will be legally allowed to perform more operations with e-money than just payment for goods (works, services). In the course of the described changes, regular updating of both accounting laws and methodological recommendations on the accounting of electronic settlements of enterprises will be required. Therefore, further research will be devoted to updating methodological recommendations on the primary recognition, evaluation and accounting of e-money under the conditions of an unprecedented and rapid transformation of the electronic settlement market and state legislation.

\section{References}

1. Pro valiutu i valiutni operatsii: Zakon Ukrainy vid 21.06.2018 r. № 2473-VIII za stanom na 21.03.2021 r. https://zakon.rada.gov.ua/laws/show/2473-19\#Text

2. Polozhennia pro elektronni hroshi v Ukraini, zatverdzhene Postanovoiu Pravlinnia Natsionalnoho banku Ukrainy vid 04.11.2010 r. № 481 za stanom na 21.03.2021 r. https://zakon.rada.gov.ua/laws/show/z1336-10\#n19

3. Pro platizhni systemy ta perekaz koshtiv v Ukraini: Zakon Ukrainy vid 05.04.2001 r. № 2346-III za stanom na 23.03.2021 r. https://zakon.rada.gov.ua/laws/show/2346-14\#Text

4. Pro virtualni aktyvy: Proekt Zakonu Ukrainy vid 11.06.2020 r. № 3637 za stanom na 18.03.2021 r. http://w1.c1.rada.gov.ua/pls/zweb2/webproc4_2? pf3516=3637\&skl=10

5. Anjelina, A. (2018). Persepsikonsumen pada penggunaan e-money. Journal of Applied Managerial Accounting, (2(2), 219-231. https://doi.org/10.30871/jama.v2i2.934 doi: 10.30871/jama.v2i2.934

6. Baddeley, M. (2004). Using E-cash in the New Economy: An Economic Analysis of Micropayment Systems. Journal of Electronic Commerce Research, 5(4), 239-253. https://goo.su/6OLk

7. Berentsen, A., \& Schär, F. (2018). The Case for Central Bank Electronic Money and the Non-case for Central Bank Cryptocurrencies. Federal Reserve Bank of St. Louis Review, (100(2), 97-106. https://www.researchgate.net/publication/324579886_The_Case_for_Central_Bank_Electronic_Money_and_the_Noncase_for_Central_Bank_Cryptocurrencies doi: 10.20955/r.2018.97-106

8. Brunnermeier, M. K., James, H., \& Landau, J.-P. (2019). The Digitalization of Money. NBER working paper series (working paper 26300). (pp. 1 - 33). https://www.nber.org/system/files/working_papers/w26300/w26300.pdf doi.org/10.3386/w26300

9. CPMI and MC. Central Bank digital currencies. (2018). Technical report, Bank for International Settlements. Committee on Payments and Market Infrastructures and Markets Committee. (pp. 1 - 28). https://www.bis.org/cpmi/publ/d174.pdf

10. Directive 2000/46/EC of the European Parliament and of the Council of 18 September 2000 on the taking up, pursuit of and prudential supervision of the business of electronic money institutions. (2000). Official Journal L 275, 0039 - 0043. https://eur-lex.europa.eu/LexUriServ/LexUriServ.do?uri= CELEX:32000L0046:EN:HTML

11. Directive 2009/110/EC of the European Parliament and of the Council of 16 September 2009 on the taking up, pursuit and prudential supervision of the business of electronic money institutions amending Directives 2005/60/EC and 2006/48/EC and repealing Directive 2000/46/EC. https://eur-lex.europa.eu/eli/dir/2009/110/oj

12. Duffie, D. (2019). Digital Currencies and Fast Payment Systems: Disruption is Coming. Stanford University Working Paper. (pp. 1 - 34). https://www.mas.gov.sg/-/media/MAS/EPG/AMPF/2019/AMPF2019---Policy-Note-1Paper---Darrell-Duffie.pdf?la=en\&hash=5CE2DD86F480472034697 BAB99E81A9E07C79F53

13. Eichengreen, B. (2019). From Commodity to Fiat and Now to Crypto: What Does History Tell Us? National Bureau of Economic Research Working Paper. (pp. 1 - 18). https://www.nber.org/papers/w25426 doi: $10.3386 / w 25426$

14. Garbowski, M., Drobyazko, S., Matveeva, V., Kyiashko, O., \& Dmytrovska, V. (2019). Financial Accounting of E-Business Enterprises. Academy of Accounting and Financial Studies Journal, 23(2), Special Issue, 1-5. https://www.researchgate.net/publication/334942641_FINANCIAL_ACCOUNTING_OF_E-

BUSINESS_ENTERPRISES

15. Kahn, C. M., Rivadeneyra, F., \& Wong, T.-N. (2019). Should the Central Bank Issue E-money? Federal Reserve Bank of St. Luis, working paper, 01-18. https://s3.amazonaws.com/real.stlouisfed.org/wp/2019/2019-003.pdf 
16. Pro elektronnu komertsiiu: Zakon Ukrainy vid 03.09.2015 r. № 675-VIII za stanom na 23.03.2021 r. https://zakon.rada.gov.ua/laws/show/675-19\#Text doi: 10.1055/a-1368-2045

17. Pro platizhni systemy ta perekaz koshtiv v Ukraini: Zakon Ukrainy vid 05.04.2001 r. № 2346-III za stanom na 28.03.2021 r. https://zakon.rada.gov.ua/laws/show/2346-14\#Text

18. Rawashden, A. M. J. (2018). The impact of electronic money use on the quality of accounting. on-case for Central Bank Cryptocurrencies. Federal Reserve Bank of St. Louis Review, 100(2), 97-106. https://www.researchgate.net/publication/324579886_The_Case_for_Central_Bank_Electronic_Money_and_the_Noncase_for_Central_Bank_Cryptocurrencies doi: 10.20955/r.2018.97-106

19. Reiss, D. G. (2018). Is money going digital? An alternative perspective on the current hype. Financial Innovation, 4(14). https://jfin-swufe.springeropen.com/articles/10.1186/s40854-018-0097-x doi: 10.1186/s40854-0180097-X

20. Tobias, A., Mancini-Griffoli, T. (2019). Fintech Notes: The Rise of Digital Money. FinTech notes (International Monetary Fund), Working Paper. (pp. 1 - 20). Washington, D.C.: International Monetary Fund. https://www.imf.org/en/Publications/fintech-notes/Issues/2019/07/12/The-Rise-of-Digital-Money-47097

21. Widiyati, D., \& Hasanah, N. (2020). Factors affecting the use of e-money. Jurnal Accountability, 9(1), 3645. https://media.neliti.com/media/publications/314881-factors-affecting-the-use-of-e-money-stu-a9160eda.pdf doi: 10.32400/ja.28881.9.1.2020.36-45

22. Wulandari, D., Soseco, T., \& Narmaditya, B. S. (2016). Analysis of the use of electronic money in efforts to support the less cash society. International Finance and Banking, (3(1), 1-10. http://www.macrothink.org/journal/index.php/ifb/article/view/8802 doi: 10.5296/ifb.v3i1.8802

23. Zhu, Y., \& Hendry, S. (2019). A framework for analyzing monetary policy in an economy with E-money. Bank of Canada, Staff working paper. (pp. 1 - 58). https://www.bankofcanada.ca/wpcontent/uploads/2019/01/swp2019-1.pdf

Received 5 April 2021

Approved 19 April 2021

Available in Internet 21.07.2021

Курган Н.В.

кандидат економічних наук, доцент

кафедра обліку і бізнес-консалтингу

Харківський національний економічний університет імені Семена Кузнеця

проспект Науки, 9-А, м. Харків, Україна, 61177

E-mail: nsk 1104@ukr.net

ORCID ID: 0000-0003-1155-6859

Аксюта В.В.

магістрант

кафедра обліку і бізнес-консалтингу

Харківський національний економічний університет імені Семена Кузнеця

проспект Науки, 9-А, м. Харків, Україна, 61177

E-mail: valeriaaksyuta@gmail.com

ORCID ID: 0000-0003-1953-4662

\section{УДОСКОНАЛЕННЯ ОБЛІКУ ЕЛЕКТРОННИХ ГРОШЕЙ НА ПІДПРИЄМСТВАХ УКРАЇНИ}

В сучасних умовах цифровізації бізнес-процесів зростає популярність платежів електронними грошима. Можливо, електронні гроші матимуть значення міжнародного платіжного засобу в майбутньому. Український ринок електронних грошей знаходиться в стадії становлення та державного врегулювання, характеризується значними законодавчими обмеженнями. Водночас все більше вітчизняних компаній залучають електронні гроші до своєї підприємницької діяльності. Тому доцільно з'ясувати сутність електронних грошей для цілей бухгалтерського обліку, а також розробити методичні рекомендації щодо їх обліку на підприємствах України. Для досягнення даної мети роботи було вирішено такі завдання: автори дослідили наукові підходи до визначення електронних грошей, класифікували сучасні типи електронних грошей на чотири ознаки, описали чинне законодавство України щодо техніки проведення розрахунків електронними грошима та їх обліку, запропонували процедуру відображення платежів електронними грошима в бухгалтерському обліку вітчизняних підприємств, обґрунтували тенденції розвитку електронних платіжних інструментів та пов'язані з цим перспективи вдосконалення українського законодавства з бухгалтерського обліку. Для вирішення мети та завдань дослідження використовувались методи спостереження, теоретичного узагальнення та групування, графічний ме- 
тод та методи наукової абстракції, індукції та дедукції. Наукова новизна отриманих результатів полягає в наступному. Автори запропонували уточнене визначення поняття «електронні гроші» як об'єкта бухгалтерського обліку, що окреслює множину електронних грошей, легалізованих в Україні. Відповідно, вдосконалено класифікацію електронних грошей для потреб бухгалтерського обліку. Електронні платіжні системи, які емітують електронні гроші та представлені на території України, було класифіковано на дев'ять груп (мережеві або карткові; персоналізовані або анонімні; фіатні електронні гроші або приватна валюта; легалізовані, нелегалізовані або заборонені електронні гроші в Україні). Покращено методичне забезпечення обліку операцій з електронними грошима у підприємства (як користувача і торгівця): розроблено додаткові субрахунки до синтетичного рахунку 33 «Інші гроші» та розроблено фрагмент робочого плану рахунків з урахуванням типів електронних грошей. Результати наукових досліджень представляють практичний інтерес для фрінансових менеджерів та бухгалтерів вітчизняних прогресивних компаній, які здійснюють розрахунки за допомогою електронних грошей.

Ключові слова: електронні гроші (е-гроші), цифрові гроші, фріатні гроші, центральний банк, електронні платіжні системи, Інтернет-гаманець, Інтернет-торгівля, облік електронних грошей.

\section{Література}

1. Про валюту і валютні операції: Закон України від 21.06.2018 р. № 2473-VIII за станом на 21.03.2021 p. URL: https://zakon.rada.gov.ua/laws/show/2473-19\#Text (дата звернення: 21.03.2021).

2. Положення про електронні гроші в Україні, затверджене Постановою Правління Національного банку України від 04.11.2010 р. № 481 за станом на 21.03.2021 p. URL: https://zakon.rada.gov.ua/laws/show/z133610\#n19 (дата звернення: 21.03.2021).

3. Про платіжні системи та переказ коштів в Україні: Закон України від 05.04.2001 р. № 2346-III за станом на 23.03.2021 p URL: https://zakon.rada.gov.ua/laws/show/2346-14\#Text (дата звернення: 23.03.2021).

4. Про віртуальні активи: Проект Закону України від 11.06.2020 р. № 3637 за станом на 18.03.2021 p. URL: http://w1.c1.rada.gov.ua/pls/zweb2/webproc4_2? pf3516=3637\&skl=10 (дата звернення: 18.03.2021).

5. Anjelina A. Persepsikonsumen pada penggunaan e-money. Journal of Applied Managerial Accounting. 2018. № 2(2). P. 219-231. URL: https://doi.org/10.30871/jama.v2i2.934 (дата звернення: 19.03.2021). doi: 10.30871/jama.v2i2.934

6. Baddeley M. Using E-cash in the New Economy: An Economic Analysis of Micropayment Systems. Journal of Electronic Commerce Research. 2004. № 4, VOL. 5. P. 239-253. URL: https://web.csulb.edu/journals/jecr/issues/20044/ Paper3.pdf (дата звернення: 19.03.2021).

7. Berentsen A., Schär F. The Case for Central Bank Electronic Money and the Non-case for Central Bank Cryptocurrencies. Federal Reserve Bank of St. Louis Review. January 2018. № 100 (2). P. 97-106. URLhttps://www.researchgate.net/publication/324579886_The_Case_for_Central_Bank_Electronic_Money_and_the_ Non-case_for_Central_Bank_Cryptocurrencies doi: 10.20955/r.2018.97-106 (дата звернення: 19.03.2021).

8. Brunnermeier M. K., James H., Landau J.-P. The Digitalization of Money. NBER working paper series. September 2019. WORKING PAPER 26300, p. $\quad 33 . \quad$ URL: https://www.nber.org/system/files/working_papers/w26300/w26300.pdf. doi: 10.3386/w26300 (дата звернення: 19.03.2021).

9. CPMI and MC. Central Bank digital currencies. Technical report, Bank for International Settlements. Committee on Payments and Market Infrastructures and Markets Committee. 2018. p. 28. URL: https://www.bis.org/ cpmi/publ/d174.pdf (дата звернення: 19.03.2021).

10. Directive 2000/46/EC of the European Parliament and of the Council of 18 September 2000 on the taking up, pursuit of and prudential supervision of the business of electronic money institutions. Official Journal L 275 , 27/10/2000, P. $0039 \quad-\quad 0043 . \quad$ URL: https://eur-lex.europa.eu/LexUriServ/LexUriServ.do?uri= CELEX:32000L0046:EN:HTML (дата звернення: 21.03.2021).

11. Directive 2009/110/EC of the European Parliament and of the Council of 16 September 2009 on the taking up, pursuit and prudential supervision of the business of electronic money institutions amending Directives 2005/60/EC and 2006/48/EC and repealing Directive 2000/46/EC. URL: https:/eur-lex.europa.eu/eli/dir/2009/110/oj (дата звернення: 21.03.2021).

12. Duffie D. Digital Currencies and Fast Payment Systems: Disruption is Coming. Stanford University Working Paper. 2019. 34 p. URL: https://www.mas.gov.sg/-/media/MAS/EPG/AMPF/2019/AMPF2019---PolicyNote-1-Paper---Darrell-Duffie.pdf?la=en\&hash=5CE2DD86F480472034697 ВAB99E81A9E07C79F53 (дата звернення: 21.03.2021).

13. Eichengreen B. From Commodity to Fiat and Now to Crypto: What Does History Tell Us? National Bureau of Economic Research Working Paper. 2019. 18 p. URL: https://www.nber.org/papers/w25426 doi: 10.3386/w25426 (дата звернення: 21.03.2021). 
14. Garbowski M., Drobyazko S., Matveeva V., Kyiashko O., Dmytrovska V. Financial Accounting of EBusiness Enterprises. Academy of Accounting and Financial Studies Journal. 2019. Volume 23, Special Issue 2. P. 1-5. URL: $\quad$ https://www.researchgate.net/publication/334942641_FINANCIAL_ACCOUNTING_OF_EBUSINESS_ENTERPRISES (дата звернення: 19.03.2021).

15. Kahn C. M., Rivadeneyra F., Wong T.-N. Should the Central Bank Issue E-money? Federal Reserve Bank of St. Luis, working paper. Jan 2019. Money, 01-18. URL: https://s3.amazonaws.com/real.stlouisfed.org/wp/2019/2019-003.pdf (дата звернення: 21.03.2021).

16. Про електронну комерцію: Закон України від 03.09.2015 р. № 675-VIII за станом на 23.03.2021 р. URL: https://zakon.rada.gov.ua/laws/show/675-19\#Text. doi: 10.1055/a-1368-2045 (дата звернення: 23.03.2021).

17. Про платіжні системи та переказ коштів в Україні: Закон України від 05.04.2001 р. № 2346-III за станом на 28.03.2021 p. URL: https://zakon.rada.gov.ua/laws/show/2346-14\#Text (дата звернення: 28.03.2021).

18. Rawashden A. M. J. The impact of electronic money use on the quality of accounting. on-case for Central Bank Cryptocurrencies. Federal Reserve Bank of St. Louis Review. January 2018. № 100(2), P. 97-106. URL: https://www.researchgate.net/publication/324579886_The_Case_for_Central_Bank_Electronic_Money_and_the_Noncase_for_Central_Bank_Cryptocurrencies. doi: 10.20955/r.2018.97-106 (дата звернення: 19.03.2021).

19. Reiss D. G. Is money going digital? An alternative perspective on the current hype. Financial Innovation. 2018. Volume 4, Article number: 14. URL: https://jfin-swufe.springeropen.com/articles/10.1186/s40854-018-0097-x. doi: 10.1186/s40854-018-0097-х (дата звернення: 19.03.2021).

20. Tobias A., Mancini-Griffoli T. Fintech Notes: The Rise of Digital Money. FinTech notes (International Monetary Fund), Working Paper. Washington, D.C. : International Monetary Fund, 2019. 20 p. URL: https:// www.imf.org/en/Publications/fintech-notes/Issues/2019/07/12/The-Rise-of-Digital-Money-47097 (дата звернення: 21.03.2021).

21. Widiyati D., Hasanah N. Factors affecting the use of e-money. Jurnal Accountability. 2020. Volume 9, № 1. P. 36-45. URL: https://media.neliti.com/ media/publications/314881-factors-affecting-the-use-of-e-money-stua9160eda.pdf. doi: 10.32400/ja.28881.9.1.2020.36-45 (дата звернення: 19.03.2021).

22. Wulandari, D., Soseco T., Narmaditya B. S. Analysis of the use of electronic money in efforts to support the less cash society. International Finance and Banking. 2016. № 3 (1). P. 1-10. URL: http://www.macrothink.org/journal/index.php/ifb/article/view/8802 doi: 10.5296/ifb.v3i1.8802 (дата звернення: 19.03.2021).

23. Zhu Y., Hendry S. A framework for analyzing monetary policy in an economy with E-money. Bank of Canada, Staff working paper. Ottawa. 2019. 58 p. URL: https://www.bankofcanada.ca/wpcontent/uploads/2019/01/swp2019-1.pdf (дата звернення: 21.03.2021).

Стаття надійшла 5.04.2021

Стаття прийнята до друку 19.04.2021

Цитування згідно ДСТУ 8302:2015

Доступно в мережі Internet 21.07.2021

Kurhan N., Aksyuta V. Improvement of electronic money accounting at Ukrainian enterprises // Food Industry Economics. 2021. Vol.13, Issue 2. P. 58-70. doi: 10.15673/fie.v13i2.2041

Cite as APA style citation

Kurhan, N., \& Aksyuta, V. (2021). Improvement of electronic money accounting at Ukrainian enterprises. Food Industry Economics, 13(2), 58-70. doi: 10.15673/fie.v13i2.2041 